\title{
The Effect of Land Use on Soil Permeability in Vojvodina
}

\author{
Katarina Milunović1. Ljiljana Nešić ${ }^{1 *}$ · Jovica Vasin². Vladimir Ćirić1 · Milivoj Belić1 . \\ Borivoj Pejić1 · Lazar Pavlović
}

${ }^{1}$ University of Novi Sad, Faculty of Agriculture, Trg Dositeja Obradovića 8, 21000 Novi Sad, Serbia

${ }^{2}$ Institute of Field and Vegetable Crops, Maksima Gorkog 30, 21000 Novi Sad, Serbia

\begin{abstract}
Summary: In order to get a comprehensive overview of the effect of land use on soil physical properties, this study was conducted on the selected representative soil samples collected at the territory of Autonomous Province of Vojvodina and included 6 types of soil present in this area. Undisturbed soil samples were taken from 61 localities, from the surface horizon $(0-30 \mathrm{~cm})$ using the Kopetzky cylinders in three replications. The rate of water flow through soil was determined by the constant flow rate method. The velocities of water flow and filtration coefficients were calculated (K-Darcy), while statistical analysis confirmed a positive correlation between soil use and soil permeability. The results showed that soils used for agricultural production have lower permeability compared to soils in forests, meadows, and pastures.

Key words: filtration coefficient, land use, soil permeability
\end{abstract}

\section{Introduction}

Soils are dynamic, changing constantly due to changes in pedogenesis. Land use in intensive agricultural production often disturbs the balance between soil forming factors which determine the direction and intensity of certain pedogenetic processes (Hadžić et al., 1999). Human activity can increase or reduce soil natural resistance to various forms of its degradation. On the other hand, soils which are not used for agricultural production are not exposed to anthropogenic influence, and their properties solely depend on the natural pedogenetic factors.

Soil degradation can be defined as a group of processes caused by human activity. These processes reduce the current and especially the future potentials of soils which represent the main condition for survival of life on Earth. Preventive measures, identifying hazards, and finding appropriate solutions are the most important steps in order to protect soils from degradation. Therefore, systematic control of soil fertility and the content of hazardous and harmful

Corresponding author:

nesiclj@polj.uns.ac.rs

Acknowledgement:

This study was conducted as a part of the Project No. TR 31072: "Status, trends and possibilities to increase the fertility of agricultural land in the Vojvodina Province", which is supported by the Ministry of Education, Science and Technological Development of Republic of Serbia substances, i.e. monitoring of soil quality is proposed (Ličina et al., 2011; Nešić et al., 2015).

Soil properties are significant indicators of its fertility and quality, therefore this paper presents research which refers to the results of soil water properties in Vojvodina Province. Water permeability is the main hydrological property of soil. When all soil pores are saturated and filled with water, water starts to filter through soil horizons (Vučić, 1987). The dynamics of water permeability is different in various soil types, even in different pedological horizons of the same pedological profile (Dugalić and Gajić, 2012). Water permeability is highly dependent on other soil properties, as well as the properties of water which appears on soil through precipitation or irrigation. Soil porosity, the presence of cracks and channels, mechanical composition, structure, compaction, soil moisture, chemical composition, length of humidification, agrotechnical and ameliorative measures, are all factors of great influence on soil water permeability. The number, size, shape and continuity of pores depend on its mechanical composition, shape of particles, set of particles, and stability of structural aggregates of soil (Miljković, 1996). Macropores which are interconnected in the direction of water filtration have the greatest water permeability. The presence of channels, cracks and tunnels made by flora and fauna, increase the intensity of water filtration through soil. Mechanical composition of soil is determined by the content of elementary soil particles. Soils with high clay content 
expand in contact with water and thus reduce the possibility of water flow through deeper soil horizons. Structural loose soils with waterproof aggregates have higher water permeability than unstructured compact soils with unstable aggregates (Dugalić and Gajić, 2012). Soil compaction occurs as a natural and anthropogenic phenomenon. In the nature, soils with a compact horizon were created as a result of unfavourable mechanical composition, water regime, and different pedogenetic processes that occur in soil (argilosynthesis and eluviation) (Hadžić et al., 1999). Soil compaction can be a result of negative anthropogenic activities, such as untimely and excessive tillage at high soil moisture, constant tillage at the same depth, destruction of structural aggregates with tools for tillage, and excessive trampling with transport vehicles (Ćirić et al., 2012). Water permeability decreases with the increase in soil compaction. Chemical composition of soil refers to its content and composition of absorbed basic cations. It is well-known that absorbed calcium ions (coagulants) have a positive influence on numerous soil properties, including water permeability. If there is a higher content of sodium ions (peptizing agent) in soil, and humidity increase, the soil suddenly and rapidly swells and becomes waterproof. Soil moisture affects the rate of water filtration. By increasing soil moisture, filtration rate reduces and leads to saturation or partial saturation of soil, thereby providing a continuous stream, stable water regime, and water filtration. Besides soil properties, some water properties also have high influence on water permeability. Increased water temperature, hydraulic pressure, and higher content of calcium ions are the factors which increase water permeability of soil (Gajić, 2006).

Determination of water permeability in soils can often be complicated. Therefore, water permeability is determined directly on the field, or in laboratory tests on
Table 1. Classification of soil based on water permeability

\begin{tabular}{ll} 
K-Darcy $\left(\mathrm{cm} \cdot \mathrm{s}^{-1}\right)$ & Water permeability of soil \\
\hline $10^{-1}, 10^{-2}$ & Very high permeability \\
$10^{-3}$ & High permeability \\
$10^{-4}$ & Medium permeability \\
$10^{-5}$ & Low permeability \\
$10^{-6}$ & Very low permeability \\
$10^{-7}$ & Waterproof \\
\hline
\end{tabular}

undisturbed soil samples. Water permeability is defined by the coefficient of filtration ( $K$ - Darcy) which represents the rate of water filtration, and is expressed in $\mathrm{cm} / \mathrm{sec}, \mathrm{m} / \mathrm{h}$, and $\mathrm{m} /$ day. At the beginning, water filtration has a higher rate, but stable values are developed after 4-5 hours and used in calculations (Vučić, 1987). Soil classification based on the values of the K-Darcy coefficient was defined by the Yugoslavian Society for Soil Science in 1971 (Table 1).

Coefficient of water filtration or rate of water permeability used as a constant rate in agricultural practice for irrigation, drainage and calculation of water loss in uncoated irrigation channels. It can also be used as an indicator of the implementation of appropriate agro-technical and amelioration practices (Vučić 1987). Dugalić and Gajić (2012) pointed out that water permeability has great significance because it affects the level of absorption of precipitation and irrigation water, the creation of surface and subsurface flow, soil water regime, intensity of erosion, creation of soil horizons, etc.

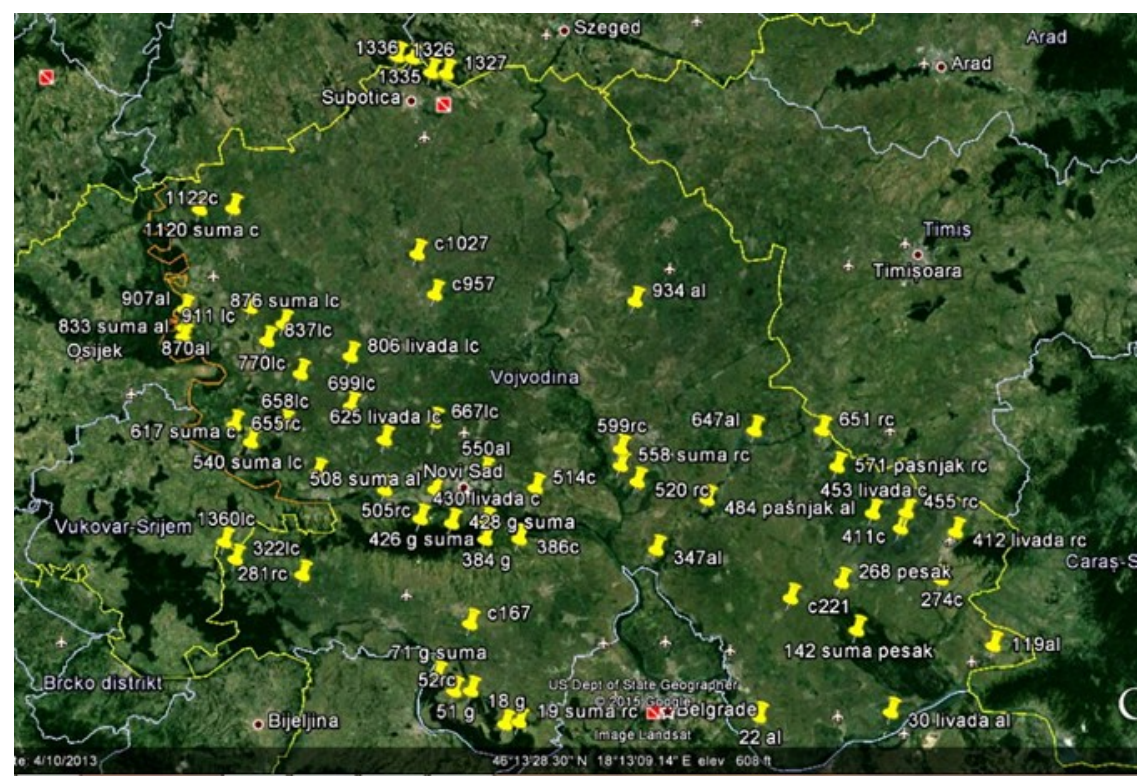

Figure 1. View of the soil sampling area in Vojvodina 


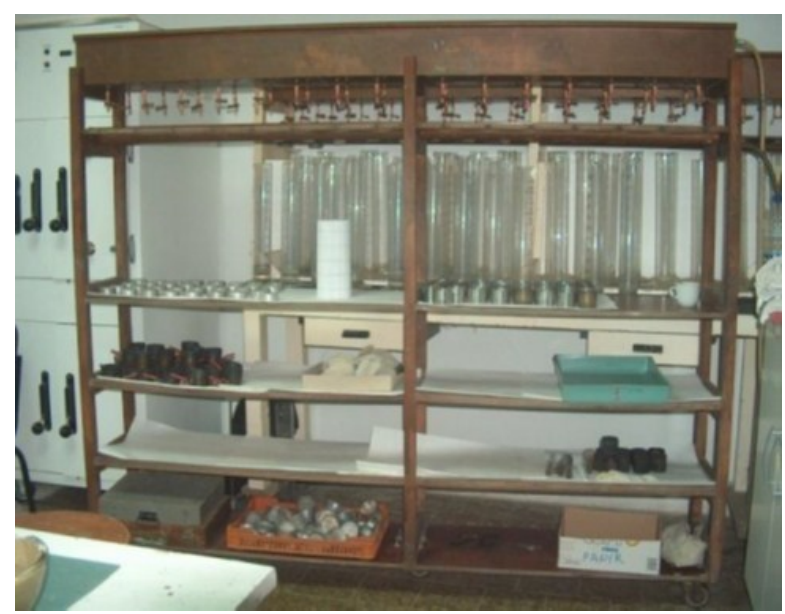

Figure 2. Determination of the filtration coefficient (K-Darcy) in non-disturbed soil samples (in Kopetzky cylinders), on the device designed by Živković

\section{Materials and Methods}

For the purpose of this research, soil samples were collected from 61 localities on the territory of Autonomous Province of Vojvodina (Figure 1). These samples represent the most frequent soil types of this area. The network of squares sized $4 \times 4 \mathrm{~km}$ was set over a soil map of Vojvodina R 1:50,000 (Nejgebauer et al., 1971), so that each soil sample represents an area of 1,600 ha. Each selected locality had the assigned GPS coordinates, marked on the digitized soil map of Vojvodina R 1:50,000 (Benka and Salvai, 2005). Soil sampling was conducted from June to July 2015. Undisturbed soil samples were taken from surface horizons of each locality with Kopetzky cylinders in 3 replications. Laboratory analyses were conducted at the Laboratory of Pedology, Faculty of Agriculture in Novi Sad.

The rate of water filtration through the soil sample was determined by the method of constant water pressure on the device constructed by Živković (Yugoslavian Society for Soil Science, 1971). Undisturbed soil samples were taken with Kopetzky cylinders and placed on a device shown in Figure 2. Afterwards, the inflow of water on taps was regulated, so as to create 4-cm-high constant water pressure above the soil samples. Timing was started when the first stream appeared on the pouring tube, and the quantity of filtered water in glass cylinders was measured in specified time periods. Measurement of water permeability lasted 4 hours because the constant rate of water filtration is established during that time frame in the majority of soil types (Belić et al., 2014).

The rate of water permeability or coefficient of filtration (K-Darcy) is considered a water constant of soil and is calculated by the formula:

$$
\begin{aligned}
& \mathrm{K}=\mathrm{Q} \cdot \mathrm{h} / \mathrm{L} \cdot \mathrm{F} \cdot \mathrm{t} \\
& \mathrm{K}=\text { rate of filtration }-\mathrm{K} \text { - Darcy coefficient }(\mathrm{cm} / \mathrm{sec}) \\
& \mathrm{Q}=\text { quantity of filtered water }\left(\mathrm{cm}^{3}\right) \text { for time } \mathrm{t}
\end{aligned}
$$

\author{
$\mathrm{L}=$ length of soil sample $(\mathrm{cm})$ \\ $\mathrm{h}=$ height of water column $(\mathrm{cm})$ \\ $\mathrm{F}=$ cross sectional area of soil sample $\mathrm{r}^{2} \pi=15$, \\ $2427 \mathrm{~cm}^{2}$
}

The results about land use, rate of water filtration and soil types, were processed by the software program Statistica8. Correlation between land use, soil type, and rate of water permeability was established using the LSD test.

\section{Results and Discussion}

Soil samples collected from the selected localities represent 6 types of soil on the territory of Autonomous Province of Vojvodina. Figure 3 shows that the most widespread type of soil on the tested localities is chernozem which occupies $41 \%$, followed by fluvisol, occupying $19 \%$, humoglay $15 \%$, eutric cambisol and arenosol 10\%, and finally vertisol 5\%. Regarding land use, the tested localities mainly consist of arable land $62 \%$, followed by forests $21 \%$, and meadows $17 \%$ (Figure 4).

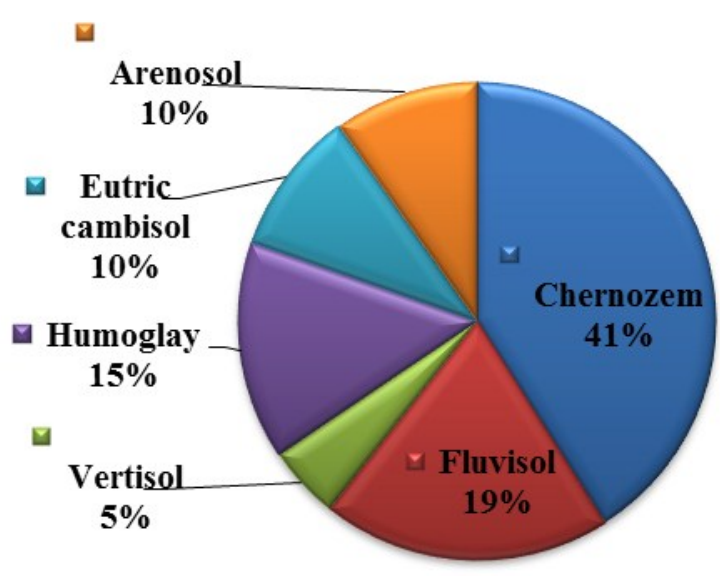

Figure 3. The percentage distribution of soil types

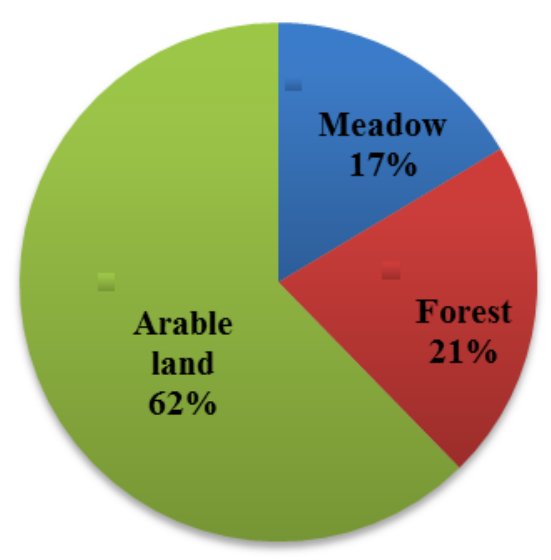

Figure 4. The percentage distribution of different land uses 


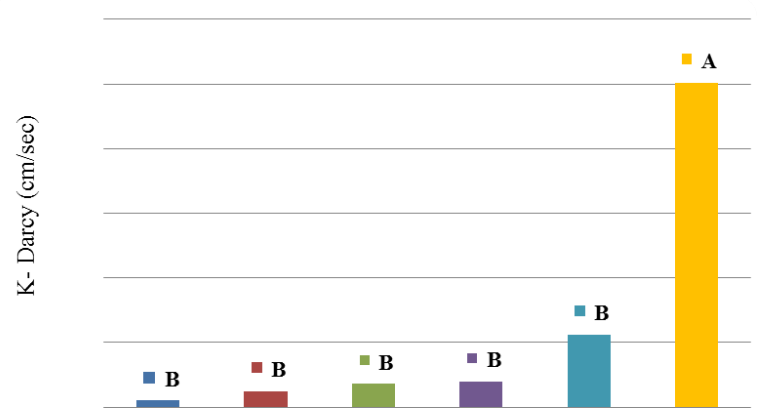

Figure 5. Effect of soil types on water permeability (Different letters show significantly different means of water permeability between soil types calculated by LSD test $(\mathrm{p}<0.05))$

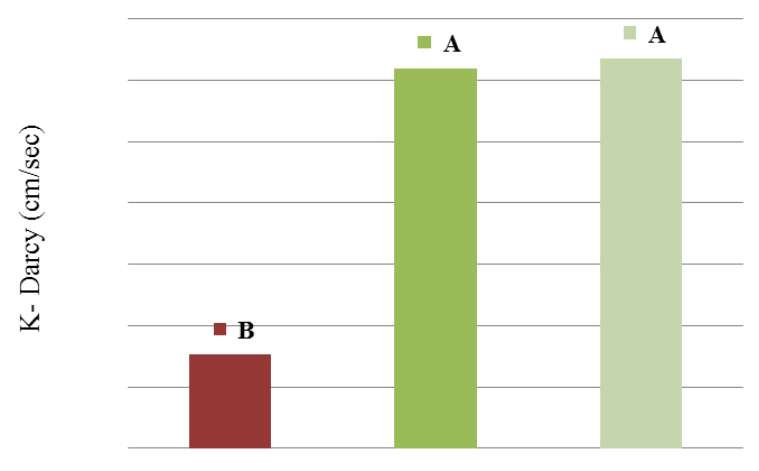

Figure 6. Effect of land uses on water permeability (Different letters show significantly different means of water permeability between land uses calculated by LSD test $(\mathrm{p}<0.05))$

The rate of water permeability for the tested soil samples varied in the interval of the order of $10^{-5}$ to $10^{-1}$ $\mathrm{cm} \cdot \mathrm{s}^{-1}$. Most of the soil samples have values of K-Darcy coefficient of the order of $10^{-3} \mathrm{~cm} \cdot \mathrm{s}^{-1}$, which means that chernozem, vertisol, eutric cambisol, fluvisol, and humoglay belong to the class of soils with high water permeability (Belić et al., 2014). The only exception is observed in arenosol, because coefficients are of the order of $10^{-1} \mathrm{~cm}^{-1}$ and this soil has very high water permeability according to soil classification.

Statistical analyses of data on soil type and rate of water permeability obtain results which do not show significant correlation, except in arenosol. Arenosol has a sandy mechanical composition which explains why it always has absolute water permeability (Figure 5).

When it comes to land use, it has been determined that arable agricultural soils have lower water permeability compared to soils of forests and meadows. Heavy mechanization, excessive use of fertilizers and pesticides, untimely tillage and irrigation with water of poor quality which are used in intensive crop production, negatively influence the physical properties of soil on which water permeability depends. Soil structure in the surface horizon deteriorates, causing soil compaction and low water permeability (Nešić et al., 2012). Figure 6 shows the results of the statistical test, and presents significant correlation between land use and water permeability of soil. These results demonstrate that water permeability as a physical property depends more on soil utilization for agricultural production than on the properties of a specific soil type.

\section{Conclusions}

After analyzing 61 soil samples collected in undisturbed condition from 6 tested soil types on the territory of Autonomous Province of Vojvodina, at the depth of $0-30 \mathrm{~cm}$, the following conclusions are drawn:

The majority of analyzed soil samples have values of K-Darcy coefficient of the order of $10^{-3} \mathrm{~cm} \cdot \mathrm{s}^{-1}$, confirming that those soils can be classified as soils with high water permeability.

Results obtained by statistical analyses show significant correlation between land use and water permeability of soil. Graphical display of these results shows that water permeability as a physical property depends more on soil utilization for agricultural production than the properties of the specific soil type.

Based on the overall research, it can be concluded that land use has a relevant influence on water permeability, as well as on other physical and chemical properties of soil. Arable agricultural soils have lower water permeability because they are under large anthropogenic influence, and therefore, deterioration of individual properties in those soils is more prominent.

\section{References}

Belić, M., Nešić, Lj., \& Ćirić, V. (2014). Praktikum izppedologije. Novi Sad: University of Novi Sad, Faculty of Agriculture.

Benka, P., \& Salvai, A. (2005). Digitalizacïja pedoloskee kearte Vojvodine za potrebe GIS-a, Melioracïe u odrivivoj poljoprivredi. Novi Sad: University of Novi Sad, Faculty of Agriculture.

Ćirić, V., Nešić, Lj., Belić, M., Savin, L., \& Simikić, M. (2012). Stanje sabijenosti černozema u proizvodnji kukuruza. Savremena poljoprivredna tehnika, 38: 21-30.

Dugalić, G., \& Gajić, B. (2012). Pedologija. Čačak: University of Kragujevac, Faculty of Agronomy.

Gajić, B. (2006). Firika zemlista. Belgrade: University of Belgrade, Faculty of Agriculture.

Hadžić, V., Marinković, B., Nešić, Lj., \& Belić, M. (1999). Problemi sabijanja zemljišta, In: Sabijanje zemljista. Novi Sad: Institut za poljoprivrednu tehniku, Institute of Field and Vegetable Crops.

Jugoslovensko društvo za proučavanje zemlijšsta (1971). Priručnik za ispitivanje zemljišta, knjiga V, Metode i strą̌ivanja fizickeih svojstava zemlisista. Beograd.

Ličina, V., Nešić, Lj., Belić, M., Hadžić, V., Sekulić, P., Vasin, J., \& Ninkov, J. (2011). The Soils of Serbia and Their Degradation. Ratar. Pourt., 48: 285-290.

Miljković, N. (1996). Osnovi pedologije. Novi Sad: University of Novi Sad, Faculty of Sciences, Institute for Georgraphy.

Nešić, Lj., Belić, M., \& Ćirić, V. (2012). Održivo korišćenje i zaštita zemljišta Vojvodine. Zbornik radova 1. naučnog skupa "Zastita životne sredine", Sremska Kamenica, str. 36-42.

Nešić, Lj., Vasin, J., Belić, M., Ćirić, V., Gligorijević, J., Milunović, K., \& Sekulić, P. (2015). Koloidna frakcija i kapacitet adsorpcije katjona u nekim zemljištima Vojvodine. Ratar. Pourt. 52: 18-23. doi:10.5937/ ratpov52-7720

Nejgebauer, V., Živković, B., Tanasijević, Đ., \& Miliković, N. (1971). Pedoloskea karta Vojvodine R 1 : 50 000. Novi Sad: Institut za poljoprivredna istraživanja.

Vučić, N. (1987). Vodni, vazdušni i toplotni rě̌im zemmijista. Novi Sad: Vojvođanska akademija nauka i umetnosti. 


\title{
Uticaj načina korišćenja na vodopropustljivost zemljišta Vojvodine
}

\section{Katarina Milunović · Ljiljana Nešić · Jovica Vasin · Vladimir Ćirić · Milivoj Belić · Borivoj Pejić · Lazar Pavlović}

\begin{abstract}
Sažetak: U cilju sagledavanja uticaja načina korišćenja zemljišta na vodno-fizička svojstva, izvršeno je istraživanje u odabranim reprezentativnim uzorcima zemljišta koji su uzeti na teritoriji Autonomne Pokrajine Vojvodine i koji obuhvataju 6 tipova zemljišta na ovom području. Za potrebe istraživanja uzorci su uzeti sa različitih lokaliteta (61 lokalitet) iz površinskog horizonta $(0-30 \mathrm{~cm})$ u nenarušenom stanju cilindrima po Kopeckom u 3 ponavljanja. Brzina proceđivanja vode kroz uzorak zemlijišta određena je metodom stalnog pritiska vodenog stuba. Matematičkim putem dobijeni su podaci o brzini vodopropustljivosti ili koeficijentu filtracije (K-Darcy). Statističkom analizom ovih podataka utvrđena je pozitivna korelacija između načina korišćenja zemljišta i brzine vodopropustljivosti. Rezultati su pokazali da zemljišta koja se koriste za poljoprivrednu proizvodnju imaju manju vodopropustljivost u odnosu na zemljišta pod šumama, livadama i pašnjacima.

Ključne reči: koeficijent filtracije, korišćenje zemljišta, vodopropustljivost zemljišta
\end{abstract}

